\title{
Water quality index assessment of groundwater in the Central Ganga Plain with reference to Raebareli district, Uttar Pradesh, India
}

\author{
Saurabh Shukla and Abhishek Saxena* \\ Faculty of Civil Engineering, Institute of Technology, Shri Ramswaroop Memorial University, Barabanki 225003 , India
}

The major problem of groundwater contamination primarily in the Indo-Gangetic alluvium is of fluoride, nitrate, arsenic, iron and salinity. One such area is Raebareli district, Uttar Pradesh, India representing the central Indo-Gangetic alluvium, where groundwater contamination through fluoride, nitrate and salinity has already been reported. However, a comprehensive picture pertaining to water quality as a whole has not been published yet. The present study deals with the changes in water quality parameters in groundwater samples of Raebareli district to present a wholesome picture. The results for water quality index (WQI) show that $7 \%$ samples in the study area are in the class of 'unsuitable for drinking' purposes, with WQI value as high as 411.5. Moreover, the results suggest that $57 \%$ and $43 \%$ of the samples in the premonsoon and post-monsoon period respectively, are under the category of 'poor' water. This study will enable the government authorities to suggest alternate drinking water sources in the affected area.

Keywords: Alluvium, fluoride, groundwater pollution, nitrate, salinity, water quality index.

GROUNDWATER is adversely affected by various pollutants, making it unsuitable for various domestic uses ${ }^{1}$. The qualitative and quantitative deterioration is primarily due to rapid urbanization, economic development and subsequent industrialization, which have led to unmonitored withdrawal of groundwater ${ }^{2}$. The groundwater quality deterioration also largely depends upon various anthropogenic and geogenic factors such as soil-water interaction, mineral composition of the soil, geochemistry, application of chemical fertilizers, industrial effluents, dumping of solid waste, residence time and reactions with pollutants, etc. ${ }^{3-5}$. There are several approaches to assess groundwater quality. However, use of water quality index (WQI) remains one of the popular methods, which confirms compliance with the standards ${ }^{6}$ and provides sufficient information to the stakeholders ${ }^{7,8}$. Numerous indexing methods exist which are also used to assess groundwater quality. Some of those are, National Sanita-

\footnotetext{
*For correspondence. (e-mail: abhishek.ce@srmu.ac.in)
}

tion Foundation Water Quality Index (NSFWQI), Bureau of Indian Standards (BIS) 10,500 weighted WQI, leachate pollution index (LPI), stream health index (SHI), Oregon water quality index (OWQI) and the Canadian Council of Ministers of the Environment water quality index (CCMEWQI) ${ }^{9,10}$. WQI makes use of large quantities of water quality data and transforms them to a single entity to describe the status of water quality ${ }^{11,12}$.

Various studies have confirmed the elevated concentration of major water contaminants such as nitrate, salinity and fluoride in groundwater of Raebareli district, Uttar Pradesh, India ${ }^{13,14}$. Although these studies analysed the variation in individual water quality parameters, no conducive study has been conducted for Raebareli district. The present study aimed at a comprehensive assessment of groundwater quality in Raebareli district. The sites in the present study are mostly rural. During field study, it was found that people are not aware about water quality standards and the compliance of water that they are consuming ${ }^{1}$. This study provides a WQI report for Raebareli district to assess groundwater suitability for drinking and other domestic uses.

\section{Description of the study area}

Raebareli district lies in the northern part of the IndoGangetic alluvial plain, between $25^{\circ} 80^{\prime} \mathrm{N}$ and $26^{\circ} 40^{\prime} \mathrm{N}$, $80^{\circ} 41^{\prime} \mathrm{E}$ and $81^{\circ} 35^{\prime} \mathrm{E}$ (ref. 1) (Figure 1). The present study was carried out in rural areas of four blocks, viz. Khiron, Lalganj, Rahi and Amawa. The district as a whole is a fairly compact tract of gently undulating topography ${ }^{1}$. The elevation varies from about $120.4 \mathrm{~m}$ amsl in the northwest to $86.9 \mathrm{~m}$ amsl in the southeast, on the banks of River Ganga. The mean annual rainfall is $\sim 1150 \mathrm{~mm}$ (ref. 1). The district is underlain by alluvial sediments of Quaternary age ${ }^{1,15}$. The sediments from older Ganga alluvium are partly undergoing denudation, while the newer alluvium is under the process of formation ${ }^{15}$. According to the reports by the Central Groundwater Board $^{16}$, a four-tier aquifer system exists in the study area. In general, the first aquifer group (unconfined aquifers) consists of clay sediments and occurs up to $100 \mathrm{~m}$ bgl. The second and third groups are characterized by the 

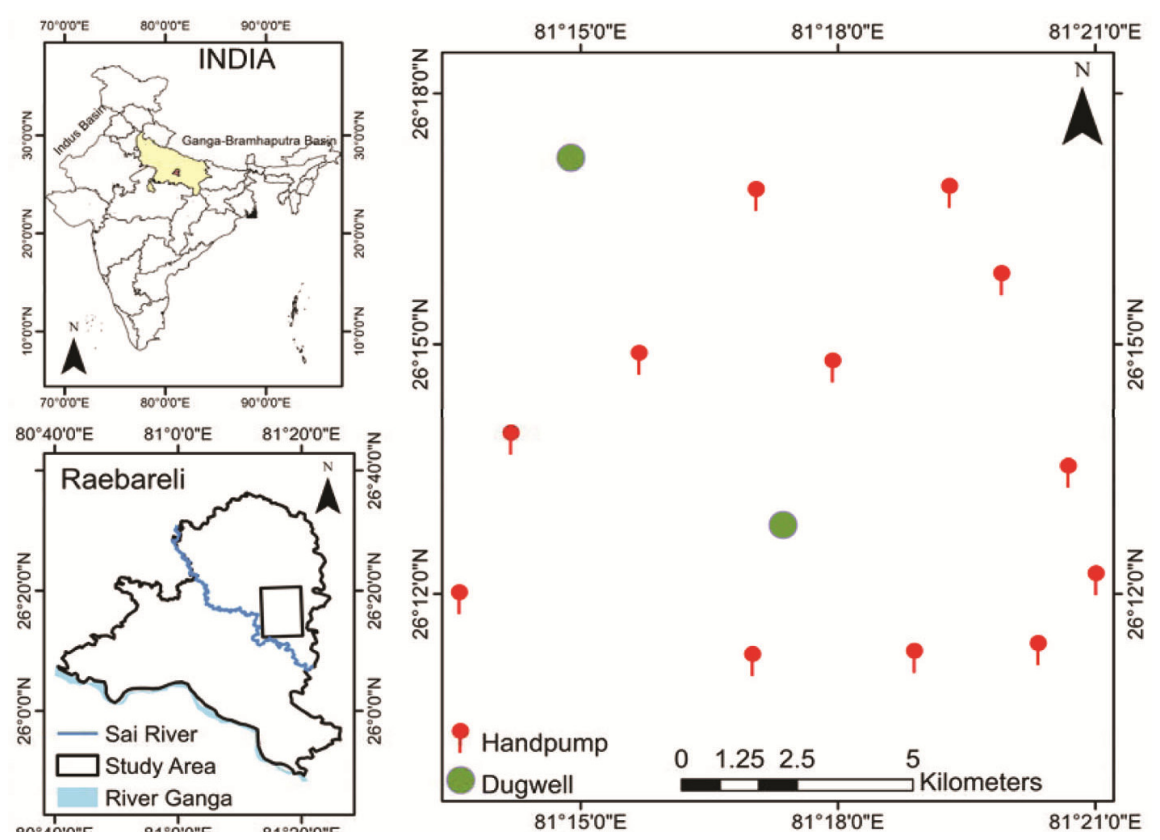

Figure 1. Location of the study area in Raebareli district, Uttar Pradesh, India.

presence of clay and kankar, with occasional sandy layers. The fourth aquifer group exists below $420 \mathrm{~m}$ and continues till 550-600 m bgl (refs 15, 16).

\section{Methodology}

Based on previous research and government reports, initially 35 water samples were collected to identify groundwater contamination. These samples were collected from hand pumps and dugwells used for domestic purposes (Figure 1). Based on the preliminary results, groundwater samples were collected for physico-chemical analysis during the pre-monsoon period (May 2016), monsoon period (August 2016) and post-monsoon period (December 2016) spread across the four blocks of Raebareli district. These samples were collected in high-density polyethylene (HDPE) bottles (1 litre capacity), which were washed and rinsed before sample collection. The samples were stored at $4^{\circ} \mathrm{C}$ until the analysis was completed. The $\mathrm{pH}$, electrical conductivity (EC) and total dissolved solids (TDS) were measured at the field after sample collection. Cations, viz. calcium, potassium, magnesium and sodium, and anions, viz. nitrate, chloride, sulphate and fluoride were analysed using ion chromatography (Metrohm850 Professional IC). Total hardness (TH) and bicarbonates were analysed using titration method ${ }^{17}$.

The ionic accuracy of the analytical data was validated by (a) calculating the charge balance (CB) between cations and anions using eq. (1) below ${ }^{1}$ and (b) calculating the EC/TDS ratio.

$$
\% \mathrm{CB}=\frac{\sum \text { Cations }-\sum \text { Anions }}{\sum \text { Cations }+\sum \text { Anions }} \times 100 .
$$

The concentration of cations and anions was expressed in meq/l. All the groundwater samples exhibited good charge balance, less than $10 \%$, which is within the acceptable limit for groundwater ${ }^{4,17}$. The EC/TDS ratio was in the range $0.55-0.7$, indicating that the analytical data had good precision ${ }^{1,17}$.

Pearson's linear correlation analysis was also done for the 14 physico-chemical parameters. The correlation matrix uses the values of correlation coefficient $r$, which signifies the strength of linear association between two parameters ${ }^{4}$. Values of $r$ ranged between -1 (strongest negative linear correlation) to +1 (strongest positive linear correlation). Pearson's correlation matrix and other statistical analyses were done using Origin Pro 2019b software ${ }^{1}$.

WQI was calculated with reference to Indian standard for drinking water (IS1500:2012), wherein the standard value for bicarbonates was taken as specified by $\mathrm{WHO}^{18}$. First, all the parameters were assigned a weight $\left(w_{i}\right)$ according to their importance in the overall quality criteria (Table 1). Maximum weights were assigned to fluoride and nitrate due to their importance in the overall water quality and their adverse effects on human health. Other parameters were assigned weight in the range 1-4 (ref. 4) based on their relative significance ${ }^{19,20}$. Secondly, the relative weight $\left(W_{i}\right)$ for all the parameters was calculated using eq. (2) (Table 1)

$$
W_{i}=\frac{w_{i}}{\sum_{i=1}^{n} w_{i}},
$$

where $W_{i}$ is the relative weight of the $i$ th parameter, $w_{i}$ the weight of the $i$ th parameter and $n$ is the total number 
Table 1. Relative weights of water quality parameters ${ }^{1}$

\begin{tabular}{lccc}
\hline Chemical parameters & $\begin{array}{c}\text { Drinking standard } \\
\text { (IS10500:2012) }\end{array}$ & Weight $\left(w_{\mathrm{i}}\right)$ & $\begin{array}{c}\text { Relative weight } \\
\left(W_{\mathrm{i}}\right)\end{array}$ \\
\hline $\mathrm{pH}$ & $6.5-8.5$ & 4 & 0.1176 \\
Total dissolved solids (TDS) & $500-2000$ & 4 & 0.1176 \\
Total hardness (TH) & $200-600$ & 2 & 0.0588 \\
Chloride & $250-1000$ & 3 & 0.0882 \\
Sulphate & $200-400$ & 4 & 0.1176 \\
Nitrate & $45-100$ & 5 & 0.1471 \\
Bicarbonates & $500^{*}$ & 3 & 0.0882 \\
Fluoride & $1-1.5$ & 5 & 0.1471 \\
Calcium & $75-200$ & 2 & 0.0588 \\
Magnesium & $30-100$ & 2 & 0.0588 \\
& & $\sum w_{i}=34$ & $\sum W_{i}=1.000$ \\
\hline
\end{tabular}

*WHO Standard (ref. 18). Note: All parameters are expressed in $\mathrm{mg} / \mathrm{l}$, except for $\mathrm{pH}$.

Table 2. Site-wise analytical summary of physico-chemical parameters for groundwater samples during pre-monsoon period

\begin{tabular}{|c|c|c|c|c|c|c|c|c|c|c|c|c|c|}
\hline & $\mathrm{pH}$ & $\mathrm{EC}$ & TDS & TH & $\mathrm{F}^{-}$ & $\mathrm{Cl}^{-}$ & $\mathrm{SO}_{4}^{2-}$ & $\mathrm{NO}_{3}^{-}$ & $\mathrm{HCO}_{3}^{-}$ & $\mathrm{Na}^{+}$ & $\mathrm{K}^{+}$ & $\mathrm{Mg}^{2+}$ & $\mathrm{Ca}^{2+}$ \\
\hline RB1 & 7.26 & 1740.00 & 1040.00 & 372.50 & 0.82 & 94.00 & 63.74 & 26.86 & 605.00 & 73.00 & 7.12 & 56.21 & 92.00 \\
\hline RB2 & 8.69 & 850.00 & 573.00 & 145.61 & 3.95 & 43.00 & 51.36 & 11.77 & 305.00 & 108.00 & 4.06 & 17.30 & 26.46 \\
\hline RB4 & 8.65 & 1000.00 & 863.00 & 269.14 & 3.86 & 86.08 & 80.27 & 39.86 & 418.00 & 140.00 & 8.91 & 37.31 & 46.24 \\
\hline RB5 & 7.44 & 490.00 & 353.00 & 193.14 & 0.98 & 26.00 & 13.27 & 3.60 & 216.00 & 18.54 & 8.34 & 21.61 & 41.69 \\
\hline RB6 & 7.24 & 470.00 & 330.00 & 185.84 & 0.25 & 19.00 & 18.64 & 0.56 & 205.00 & 24.80 & 2.83 & 17.97 & 39.00 \\
\hline RB8 & 7.43 & 1350.00 & 910.00 & 219.04 & 1.85 & 181.90 & 54.20 & 1.49 & 380.00 & 214.00 & 9.73 & 28.36 & 40.93 \\
\hline RB9 & 7.26 & 1680.00 & 1180.00 & 427.83 & 2.04 & 224.68 & 107.18 & 14.16 & 478.00 & 228.00 & 10.25 & 48.00 & 67.00 \\
\hline RB10 & 7.24 & 700.00 & 535.00 & 348.78 & 1.77 & 73.84 & 18.90 & 17.12 & 285.00 & 21.38 & 4.05 & 46.74 & 62.57 \\
\hline RB11 & 7.79 & 4200.00 & 2893.00 & 1002.77 & 8.28 & 531.72 & 410.00 & 139.76 & 1012.00 & 529.00 & 18.97 & 195.00 & 50.10 \\
\hline RB12 & 7.57 & 420.00 & 284.00 & 178.72 & 0.18 & 26.07 & 13.31 & 0.23 & 171.00 & 43.24 & 5.43 & 20.60 & 11.34 \\
\hline RB13 & 7.53 & 1010.00 & 902.00 & 260.66 & 0.82 & 155.92 & 76.81 & 2.51 & 395.00 & 188.00 & 12.64 & 41.00 & 29.42 \\
\hline RB14 & 7.49 & 1060.00 & 930.00 & 367.20 & 0.13 & 174.34 & 64.34 & 112.34 & 310.00 & 174.00 & 7.46 & 63.00 & 24.51 \\
\hline Mean & 7.67 & 1250.71 & 910.29 & 353.65 & 2.03 & 141.25 & 88.59 & 35.72 & 387.43 & 148.50 & 8.03 & 48.48 & 47.92 \\
\hline Maximum & 8.69 & 4200.00 & 2893.00 & 1002.77 & 8.28 & 531.72 & 410.00 & 139.76 & 1012.00 & 529.00 & 18.97 & 195.00 & 97.68 \\
\hline SD & 0.55 & 964.47 & 664.44 & 221.17 & 2.16 & 141.61 & 101.25 & 51.22 & 216.41 & 135.86 & 4.21 & 45.51 & 24.65 \\
\hline
\end{tabular}

Note: Electrical conductivity (EC) in $\mu \mathrm{S} / \mathrm{cm}$; all other parameters in $\mathrm{mg} / \mathrm{l}$, except $\mathrm{pH}$. SD, Standard deviation.

of parameters. Next, a quality rating value $\left(q_{i}\right)$ was assigned to each parameter, which was calculated using eq. (3):

$$
q_{i}=\left(\frac{C_{i}}{S_{i}}\right) \times 100,
$$

where $q_{i}$ is the quality rating of the $i$ th parameter, $C_{i}$ the concentration of the $i$ th parameter in each water sample and $S_{i}$ is the standard value for each chemical parameter according to IS10500:2012. Further, sub-index (SI) for each parameter was calculated, which was used to calculate WQI using the following equations

$$
\begin{aligned}
& \mathrm{SI}_{i}=W_{i} \times q_{i}, \\
& \mathrm{WQI}=\sum \mathrm{SI}_{i-n},
\end{aligned}
$$

where $\mathrm{SI}_{i}$ is the sub-index for the $i$ th parameter.
The computed WQI values were classified into five categories as follows $^{21}$ : excellent water $(\mathrm{WQI}<50)$, good water (WQI: 50-100), poor water (WQI: 101-200), very poor water (WQI: 201-300) and not suitable for drinking purposes $(\mathrm{WQI}>300)^{22}$.

\section{Results and discussion}

Tables 2-4 summarize the results of various physicochemical parameters. The $\mathrm{pH}$ value ranged from 7.16 to 8.69 , which suggests that groundwater in the study area is slightly alkaline. TDS was recorded at a minimum of $260 \mathrm{mg} / 1$ during monsoon and a maximum of $3060 \mathrm{mg} / \mathrm{l}$ during the post-monsoon period. Increased levels of sodium and bicarbonate ions might be the reason for increase in TDS during post-monsoon period. Consuming water with high concentration of TDS may result in undesirable taste and gastrointestinal irritation ${ }^{12}$. The high 
RESEARCH ARTICLES

Table 3. Site-wise analytical summary of physico-chemical parameters for groundwater samples during monsoon period

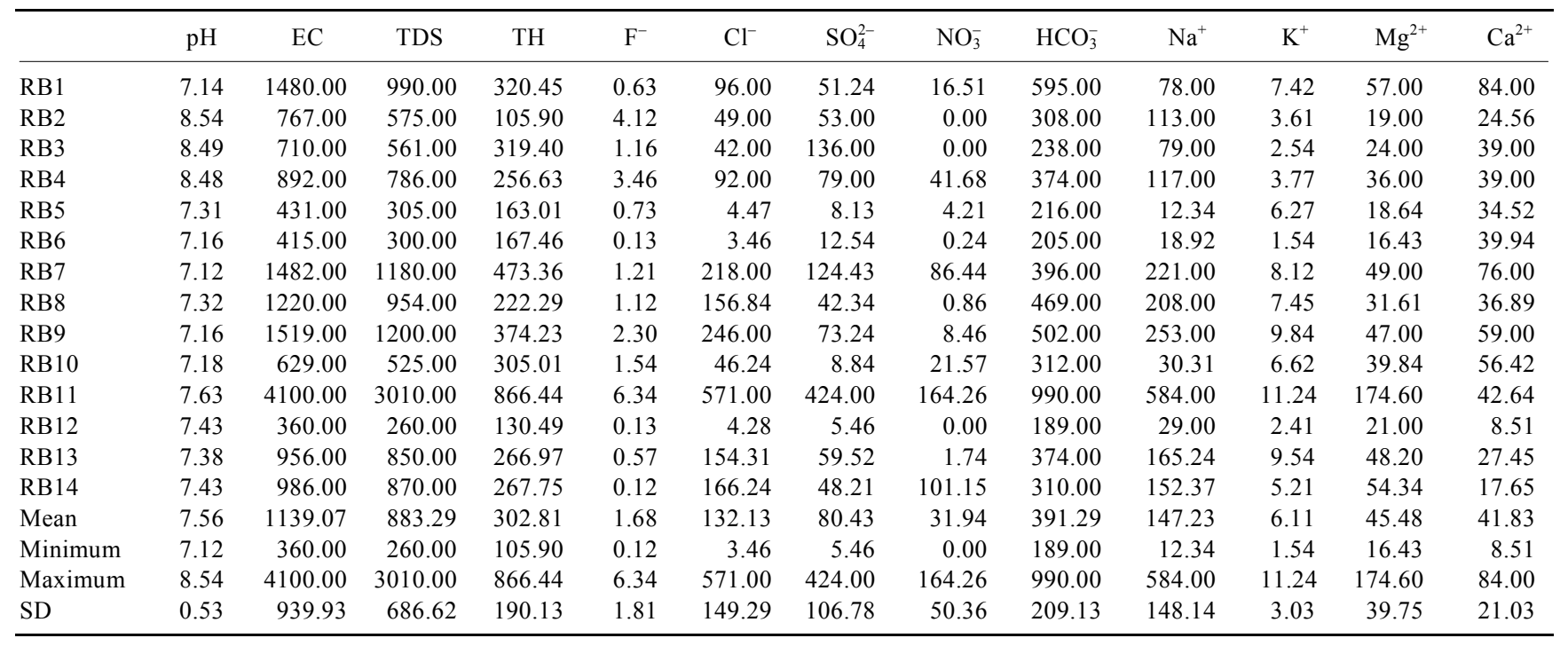

Note: $\mathrm{EC}$ in $\mu \mathrm{S} / \mathrm{cm}$; all other parameters in $\mathrm{mg} / \mathrm{l}$, except $\mathrm{pH}$.

Table 4. Site-wise analytical summary of physico-chemical parameters for groundwater samples during post-monsoon period

\begin{tabular}{|c|c|c|c|c|c|c|c|c|c|c|c|c|c|}
\hline & $\mathrm{pH}$ & $\mathrm{EC}$ & TDS & $\mathrm{TH}$ & $\mathrm{F}^{-}$ & $\mathrm{Cl}^{-}$ & $\mathrm{SO}_{4}^{2-}$ & $\mathrm{NO}_{3}^{-}$ & $\mathrm{HCO}_{3}^{-}$ & $\mathrm{Na}^{+}$ & $\mathrm{K}^{+}$ & $\mathrm{Mg}^{2+}$ & $\mathrm{Ca}^{2+}$ \\
\hline RB1 & 7.21 & 1676.00 & 1050.00 & 338.11 & 0.76 & 104.00 & 59.43 & 20.55 & 588.00 & 93.00 & 6.00 & 51.09 & 89.00 \\
\hline RB2 & 8.63 & 780.00 & 595.00 & 127.42 & 3.63 & 41.00 & 49.00 & 8.43 & 326.00 & 125.00 & 2.59 & 16.84 & 23.24 \\
\hline RB4 & 8.53 & 926.00 & 685.00 & 256.05 & 3.72 & 73.16 & 71.83 & 27.92 & 328.00 & 115.00 & 3.77 & 24.00 & 38.00 \\
\hline RB5 & 7.38 & 463.00 & 292.00 & 178.05 & 0.84 & 5.31 & 10.44 & 2.14 & 205.00 & 15.73 & 8.34 & 17.00 & 28.00 \\
\hline RB6 & 7.19 & 434.00 & 314.00 & 179.64 & 0.27 & 4.53 & 14.85 & 0.46 & 218.00 & 21.37 & 2.83 & 15.00 & 37.00 \\
\hline RB8 & 7.38 & 1265.00 & 910.00 & 196.08 & 1.73 & 172.34 & 49.84 & 1.24 & 406.00 & 218.00 & 3.80 & 24.12 & 38.73 \\
\hline RB9 & 7.19 & 1563.00 & 1140.00 & 439.93 & 1.87 & 234.21 & 84.37 & 10.61 & 487.00 & 234.00 & 5.67 & 42.00 & 51.00 \\
\hline RB10 & 7.21 & 674.00 & 560.00 & 326.76 & 1.71 & 64.31 & 14.26 & 19.10 & 326.00 & 24.15 & 3.84 & 43.24 & 59.53 \\
\hline RB11 & 7.73 & 4150.00 & 3060.00 & 937.47 & 7.62 & 509.83 & 396.14 & 123.43 & 1145.00 & 636.00 & 15.26 & 161.00 & 43.41 \\
\hline RB12 & 7.49 & 396.00 & 285.00 & 159.36 & 0.21 & 5.43 & 7.26 & 0.43 & 204.00 & 40.05 & 3.45 & 13.00 & 9.27 \\
\hline RB13 & 7.43 & 975.00 & 790.00 & 251.13 & 0.67 & 166.29 & 64.24 & 2.34 & 326.00 & 153.00 & 4.75 & 45.47 & 25.61 \\
\hline RB14 & 7.46 & 1024.00 & 860.00 & 337.12 & 0.16 & 173.14 & 55.63 & 108.26 & 281.00 & 160.00 & 5.48 & 49.00 & 20.74 \\
\hline Mean & 7.61 & 1190.43 & 887.21 & 329.31 & 1.85 & 132.69 & 82.52 & 31.21 & 393.43 & 152.95 & 5.45 & 41.34 & 42.11 \\
\hline Maximum & 8.63 & 4150.00 & 3060.00 & 937.47 & 7.62 & 509.83 & 396.14 & 123.43 & 1145.00 & 636.00 & 15.26 & 161.00 & 89.00 \\
\hline $\mathrm{SD}$ & 0.54 & 951.98 & 696.77 & 208.46 & 2.00 & 141.72 & 99.53 & 46.11 & 240.62 & 158.46 & 3.20 & 37.32 & 22.79 \\
\hline
\end{tabular}

Note: $\mathrm{EC}$ in $\mu \mathrm{S} / \mathrm{cm}$, all other parameters in $\mathrm{mg} / 1$, except $\mathrm{pH}$.

TDS value observed at site RB11 (dugwell), located in the vicinity of agricultural fields (Amawa block), may be associated with percolation of irrigation water which contains fertilizers and animal waste. The EC values varied between 420 and $4200 \mu \mathrm{S} / \mathrm{cm}$ during pre-monsoon and between 396 and $4150 \mu \mathrm{S} / \mathrm{cm}$ during the post-monsoon period. The high values of EC are proportional to the ionic strength of water and chiefly contribute towards the salinity in groundwater. Moreover, alkaline earth metals are exceeded by alkali earth metals in majority of the groundwater samples. The association of sodium and high chloride concentration suggests that the study area has been adversely affected by groundwater salinity. The weak acids also show dominance over the strong acids, which suggests slightly alkaline nature of water, and is in coherence with mean values of $\mathrm{pH}$.
The results from ion chemistry show that $\mathrm{HCO}_{3}^{-}$is the leading anion and $\mathrm{Na}^{+}$is the leading cation in all the groundwater samples during all seasons. $\mathrm{HCO}_{3}^{-}$varied between 171 and $1145 \mathrm{mg} / \mathrm{l}$. High values of bicarbonates are associated with kankar (calcrete) formation ${ }^{22}$. The higher bicarbonate values during post-monsoon period may be attributed to dissolution of rocks during heavy rainfall and groundwater movement ${ }^{22,23}$. Among the cations, the compliance of $\mathrm{Mg}^{2+}$ was very low, viz. $28.57 \%$ during all seasons. It has been reported that elevated magnesium levels $(>100 \mathrm{mg} / \mathrm{l})$ are associated with cardiovascular diseases and hypertension, which may also cause death ${ }^{24,25}$. Moreover, concentration of $\mathrm{Na}^{+}$varied from $12.34 \mathrm{mg} / 1$ (monsoon) to $636 \mathrm{mg} / 1$ (post-monsoon). The high values of sodium indicate high sodicity of the soil. Among the anions, chloride concentration varied 

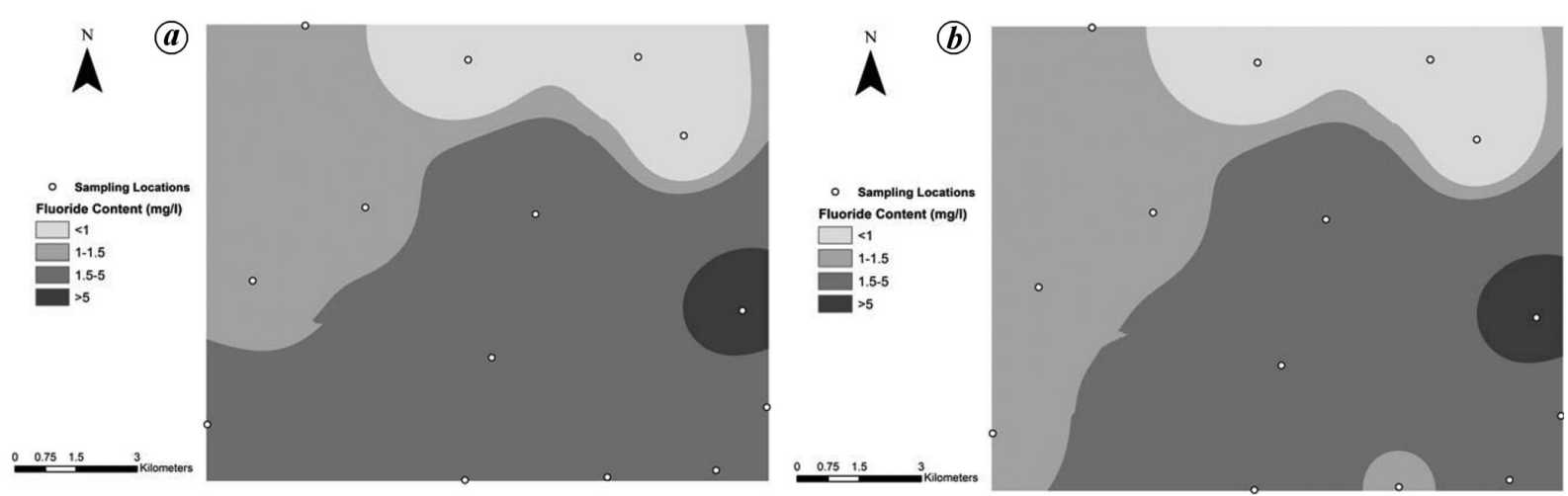

Figure 2. Spatial variation of fluoride content during $(\boldsymbol{a})$ pre-monsoon and $(\boldsymbol{b})$ post-monsoon periods.
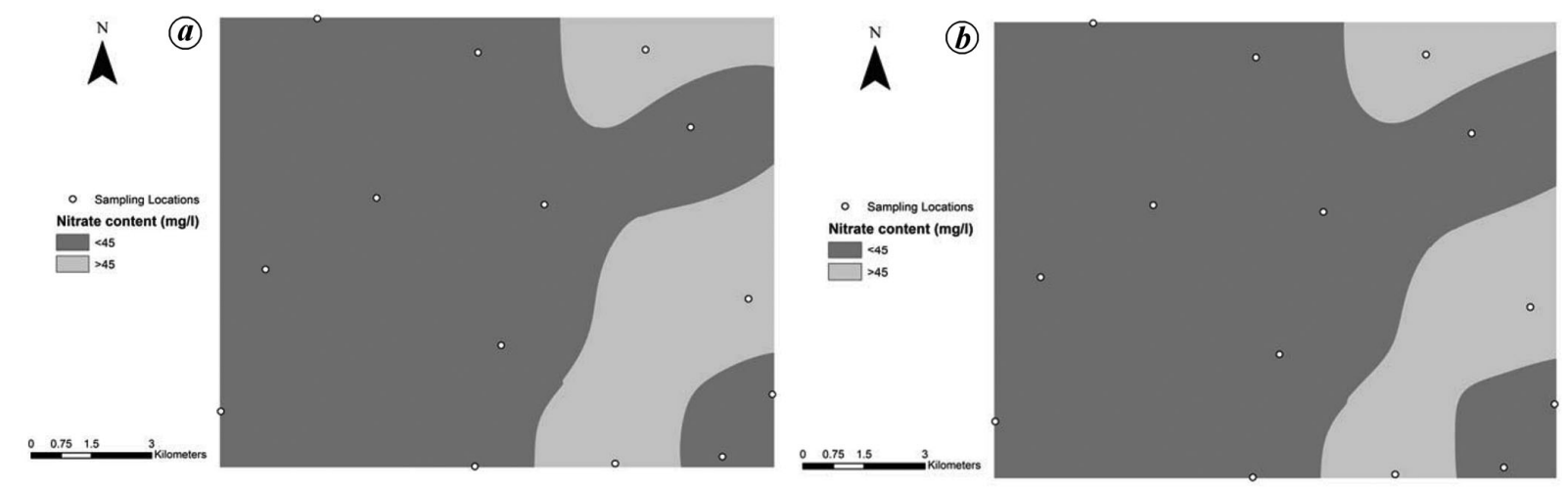

Figure 3. Spatial variation of nitrate content during $(\boldsymbol{a})$ pre-monsoon and (b) post-monsoon periods.

from $3.46 \mathrm{mg} / 1$ (monsoon) at site RB6 to $571 \mathrm{mg} / 1$ (monsoon) at site RB11. Moreover, it was observed that three samples during pre-monsoon and two samples during monsoon and post-monsoon periods were not within the permissible limit with respect to chloride. Also, chloride is an important inorganic anion and its presence in groundwater is often related with improper sanitary conditions, irrigation practices and mismanagement of industrial discharge ${ }^{26}$. Among the anions, compliance of $\mathrm{F}^{-}(42.86 \%)$ ion was the lowest. Figure 2 shows the spatial variation of fluoride contamination in groundwater. Maximum fluoride concentration of $8.28 \mathrm{mg} / 1$ was found at RB11 during pre-monsoon period. This fact is also coherent with a health impact survey done in the study area, where many people were found to be suffering from dental fluorosis. Moreover, elevated nitrate levels were also found in the study area. The maximum value of nitrate was $164.26 \mathrm{mg} / \mathrm{l}$ in the sample collected from a dugwell in Amawa block (RB11) during monsoon, and the mean value was 35.72 and $31.21 \mathrm{mg} / 1$ during premonsoon and post-monsoon periods respectively. Figure 3 shows the spatial variation of nitrate in groundwater. Higher nitrate values $(>10 \mathrm{mg} / \mathrm{l})$ in groundwater suggest interventions from anthropogenic sources ${ }^{27}$. Since the area is mostly agriculture-dominated, excessive fertilizer use might be the reason for nitrate in groundwater ${ }^{1,27}$. The presence of nitrate in groundwater also indicates poor sanitary conditions in the surrounding areas. There has been an emphasis on 'toilet for every home' under the 'Swachh Bharat Mission' in India. It may be possible that lack of technical supervision in the study area might have resulted in faulty design of septic tanks and leaching pits, leading to leaching out of sewage. Moreover, since the soil is of sandy type, sewage might have percolated into the groundwater causing higher nitrate content in it. However, sporadic occurrence of nitrate in the study area also suggests the possible contribution of geogenic factors $^{27}$. Consuming water with high nitrate content ( $>45 \mathrm{mg} / \mathrm{l}$ ) might cause 'blue baby syndrome', cancer and thyroid problems ${ }^{28,29}$.

The value of WQI was in the range 43.27-411.55 during pre-monsoon, 37.75-382.70 during monsoon and 40.36-390.01 during post-monsoon periods. It is noteworthy that percentage of samples in 'excellent' and 'unsuitable for drinking' categories remained the same throughout the duration of the study. However, the number of samples in 'good' category increased during monsoon and post-monsoon periods due to the probability of dilution factor in groundwater (Table 5).

Figure 4 shows the WQI values for all the sampling locations. It can be observed that WQI largely depends upon the concentration of nitrate and fluoride in the 
Table 5. Water quality index (WQI) and per cent compliance with different water types

\begin{tabular}{|c|c|c|c|c|}
\hline \multirow[b]{2}{*}{ WQI range } & \multirow[b]{2}{*}{ Water type } & \multicolumn{3}{|c|}{ Per cent compliance } \\
\hline & & Pre-monsoon & Monsoon & Post-monsoon \\
\hline$<50$ & Excellent & 14 & 14 & 14 \\
\hline $51-100$ & Good & 21 & 36 & 36 \\
\hline $101-200$ & Poor & 57 & 43 & 43 \\
\hline $201-300$ & Very poor & 0 & 0 & 0 \\
\hline$>300$ & Unsuitable for drinking & 7 & 7 & 7 \\
\hline
\end{tabular}

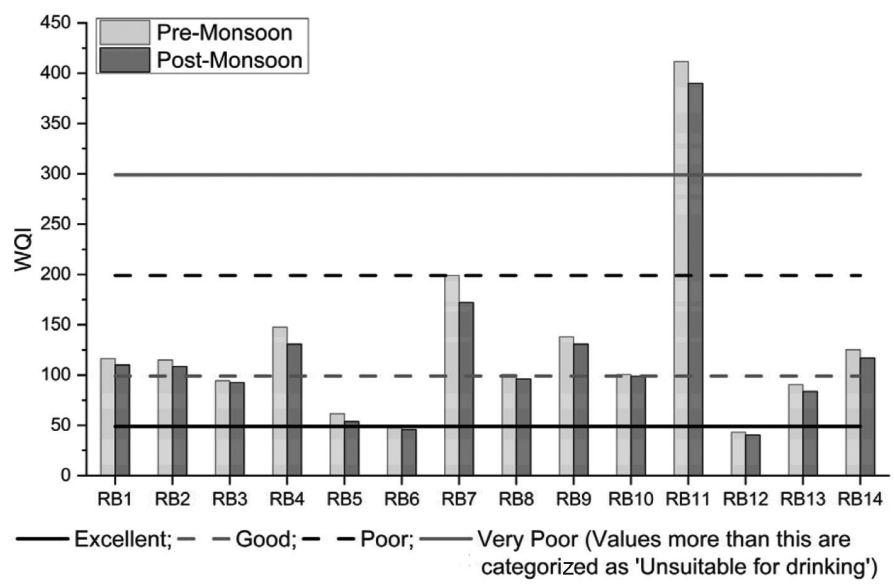

Figure 4. Site-wise variation of water quality index for pre-monsoon and post-monsoon periods

groundwater. The site RB11, where both nitrate and fluoride were recorded in excess of the permissible limits, also recorded an alarmingly high WQI value of 411.5 . Water samples showing high values of WQI (>300) were categorized as 'unsuitable' not only for drinking and domestic purposes, but also for cattle feeding. Moreover, in the sites where concentration of nitrate was high but fluoride was within the permissible limits, water quality was under the 'poor' category, i.e. not suitable for domestic purposes but can be used for cleaning and other such purposes. Site location RB7 (Mark-II handpump) exhibited 'poor' category of drinking water, associated with higher values of nitrate and TDS in the study area. Few other sites (RB1, RB2, RB4, RB9 and RB14) were categorized as 'poor' with respect to WQI. However, these sites were under 'poor' category due to high TDS and fluoride concentration, which resulted in higher WQI values. Incorporating the WQI values in the correlation matrix enables us to identify the importance of analysed parameters in influencing WQI (Table 6). The correlation matrix verifies that WQI shows good correlation with EC, $\mathrm{TH}, \mathrm{TDS}, \mathrm{SO}_{4}^{2-}, \mathrm{Cl}^{-}, \mathrm{HCO}_{3}^{-}, \mathrm{F}^{-}, \mathrm{Na}^{+}, \mathrm{NO}_{3}^{-}, \mathrm{Mg}^{2+}$ and $\mathrm{K}^{+}$, suggesting the importance of these parameters in shaping the drinking water quality.

\section{Conclusion}

The water quality analysis of groundwater in this study enables us to evaluate the groundwater quality of Raebareli district through computation of WQI. Also, WQI can be used as a good tool to authenticate and present the comprehensive status of groundwater contamination and its potential adverse impacts on residents of the study area. The important findings of this study are as follows:

- The maximum WQI value of 411.5 was reported from the water sample collected from a dugwell in Amawa block (site RB11). Also, $58 \%$ and $43 \%$ of the samples were reported under 'poor' and 'very poor' categories of WQI respectively, throughout the year.

- The detailed WQI analysis suggests that the area is mainly affected by fluoride, nitrate and salinity. Detailed analysis reflects sporadic occurrence of these parameters in the study area. High values of these parameters result in overall poor water quality which makes the groundwater unsuitable for drinking.

- The source of elevated fluoride concentration appears to be geogenic in nature (possible weathering of mica minerals $)^{8}$. Whereas the reason for high nitrate concentration in groundwater may be because of anthropogenic factors such as heavy fertilizer application, improper sewer design, industrial discharge, etc. ${ }^{14,28}$.

- Continuous consumption of groundwater with high WQI values by people living in the area, may result in dental fluorosis, skeletal fluorosis, blue baby syndrome, etc.

This study could help bring awareness among the people and present a wholesome picture pertaining to 


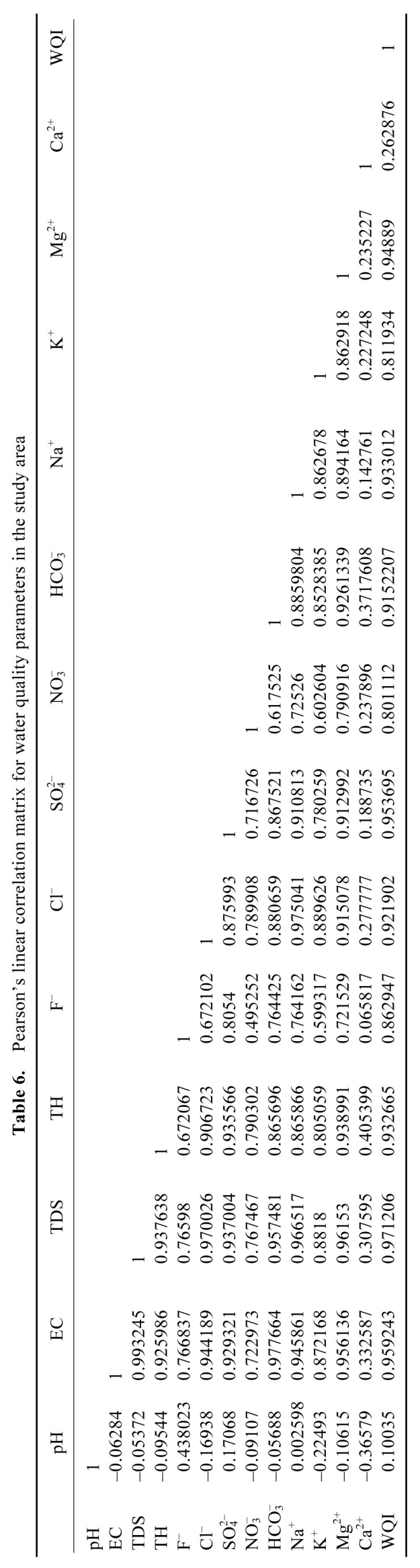


groundwater quality problems of the study area. Moreover, WQI can also be used to categorize the sources (hand pumps, dugwells, etc.) of drinking water. The sources with high WQI should be demarcated and not recommended for use. In addition, proper treatment methods such as cost-effective filters may be proposed in the study area. Moreover, this study could be important for policymakers and the involved stakeholders in shaping policies and may also assist the various government officials towards better groundwater management. It is also recommended that the concept of WQI should be adopted for areas affected by similar problems, which would help in providing the population access to safe drinking water.

Disclosure statement: The authors declare no potential conflict of interest.

1. Shukla, S. and Saxena, A., Groundwater quality and associated human health risk assessment in parts of Raebareli district, Uttar Pradesh, India. Groundw. Sustain. Dev., 2020, 10; https:// doi.org/10.1016/j.gsd.2020.100366.

2. Chang, H. et al., High efficiency nutrients reclamation from landfill leachate by microalgae Chlorella vulgaris in membrane photobioreactor for bio-lipid production. Bioresour. Technol., 2018, 266, 374-381.

3. Mehdi, Z., Fuzieh, S. and Ezzat, R., Hydrogeochemical characterization of major factors affecting the quality of groundwater in southern Iran, Janah Plain. Chem. Erde, 2014, 74, 671-680.

4. Batabyal, A. K. and Chakraborty, S., Hydrogeochemistry and water quality index in the assessment of groundwater quality for drinking uses. Water Environ. Res., 2015, 87, 607-614.

5. Mohamad, S., Arzaneh, F. and Mohamad, J. P., Quality of groundwater in an area with intensive agricultural activity. Expos. Health, 2016, 8, 93-105.

6. Nasirian, M., A new water quality index for environmental contamination contributed by mineral processing: a case study of Amang (tin tailing) processing activity. J. Appl. Sci., 2007, 7(20), 29772987.

7. Singh, R. P., Nath, S., Prasad, S. C. and Nema, A. K., Selections of suitable aggregation function for estimation of aggregate pollution for river Ganges in India. J. Environ. Eng., 2008, 134(8), 689-701.

8. Goel, P., Saxena, A., Singh, D. S. and Verma, D., Impact of rapid urbanization on water quality index in groundwater fed Gomati River, Lucknow, India. Curr. Sci., 2018, 114(3), 650-654.

9. Rana, R., Ganguly, R. and Gupta, A. K., Indexing method for assessment of pollution potential of leachate from non-engineered landfill sites and its effect on ground water quality. Environ. Monit. Assess., 2018, 190, 46; https://doi.org/10.1007/s10661-017-6417-1.

10. Khatri, N., Tyagi, S., Rawtani, D., Tharmavaram, M. and Kamboj, R. D., Analysis and assessment of ground water quality in Satlasana Taluka, Mehsana district, Gujarat, India through application of water quality indices. Groundw. Sustain. Dev., 2020, 10, 100321; https://doi.org/10.1016/j.gsd.2019.100321.

11. Reza, R. and Singh, G., Assessment of ground water quality status by using water quality index method in Orissa, India. World Appl. Sci. J., 2010, 9(12), 1392-1397.

12. Chaurasia, A. K., Pandey, H. K., Tiwari, S. K., Prakash, R., Pandey, P. and Ram A., Groundwater quality assessment using water quality index (WQI) in parts of Varanasi, Uttar Pradesh, India. $J$. Geol. Soc. India, 2018, 92, 76-82.
13. Srivastava, S. and Kumar, S., Fluoride concentration in ground waters at Raebareli district (India). J. Environ. Sci. Eng., 2011, 53(1), 85-92.

14. Sahu, P., Kisku, G. C., Singh, P. K., Kumar, V., Kumar, P. and Shukla, N., Multivariate statistical interpretation on seasonal variations of fluoride-contaminated groundwater quality of Lalganj Tehsil, Raebareli District (UP), India. Environ. Earth Sci., 2018, 77, 484-494.

15. Khanna, S. P., Hydrogeology of Central Ganga Plain, U.P. Gangetic Plain. Tera Incogn., 1992, 23-27.

16. CGWB, Aquifer Systems of India, Central Ground Water Board, Government of India, 2012.

17. APHA, Standard Methods for the Examination of Water and Wastewater, American Public Health Association, Washington, DC, USA, 2012, 22nd edn.

18. WHO, Guidelines for Drinking Water Quality, World Health Organization, Geneva, 2011, 4th edn.

19. Brown, R. M., McClelland, N. I., Deininger, R. A. and Tozer, R. G., Water quality index - do we dare? Water Sewage Works, 1970, 117(10), 339-343.

20. Krishnan, J. S. R., Rambabu, K. and Rambabu, C., Studies on water quality parameters of bore waters of Reddigudum Mandal. Indian J. Environ. Prot., 1995, 16(4), 91-98.

21. Yidana, S. M. and Yidana, A., Assessing water quality using water quality index and multivariate analysis. Environ. Earth Sci., 2010, 59, 1461-1573.

22. Şener, S., Şener, E. and Davraz, A., Evaluation of water quality using water quality index (WQI) method and GIS in Aksu River (SW-Turkey). Sci. Total Environ., 2017, 584-585, 131-144.

23. Subramani, T., Elango, L., Srinivasalu, S. and Marikio, T., Geological setting and groundwater chemistry in Chithar River basin, Tamil Nadu, India. Indian. Miner., 2005, 39, 108-119.

24. Yang, C.-Y. and Chiu, H.-F., Calcium and magnesium in drinking water and the risk of death from hypertension. Am. J. Hypertens., 1999, 12(9), 894-899; https://doi.org/10.1016/S0895-7061(99) 00065-5.

25. Sengupta, P., Potential health impacts of hard water. Int. J. Prev. Med., 2013, 4, 866-875.

26. Selvakumar, S., Chandrasekar, N. and Kumar, G., Hydrogeochemical characteristics and groundwater contamination in the rapid urban development areas of Coimbatore, India. Water Resour. Ind., 2017, 17, 26-33.

27. Srivastava, S. K. and Ramanathan, A. L., Geochemical assessment of fluoride enrichment and nitrate contamination in groundwater in hard-rock aquifer by using graphical and statistical methods. J. Earth Syst. Sci., 2018, 127, 104-126.

28. Buvaneshwari, S. et al., Groundwater resource vulnerability and spatial variability of nitrate contamination: insights from high density tubewell monitoring in a hard rock aquifer. Sci. Total Environ., 2017, 579, 838-847.

29. Shukla, S. and Saxena, A., Global status of nitrate contamination in groundwater: its occurrence, health impacts, and mitigation measures. In Handbook of Environmental Materials Management (ed. Hussain, C. M.). Springer, Cham, Switzerland, 2018, pp. 869-888.

ACKNOWLEDGEMENTS. We thank Dr A. K. Singh (ViceChancellor, Shri Ramswaroop Memorial University, Barabanki) for providing the necessary facilities for this study. We also thank Prof. Surendra Kumar, for insights and valuable feedbacks.

Received 6 November 2019; revised accepted 19 July 2020

doi: $10.18520 / \mathrm{cs} / \mathrm{v} 119 / \mathrm{i} 8 / 1308-1315$ 